\title{
A Case for an Opt-Out Organ Donation System in Canada
}

\author{
Taylor Aust ${ }^{1}$ \\ ${ }^{1}$ Faculty of Medicine, Université de Montréal
}

A B S TR A C T

This commentary supports an 'opt-out' system for organ donation in Canada. To begin, it examines the state of organ donation in our country and presents both the 'opt-in' and 'opt-out' schemes. Then, it argues in favour of implementing 'opt-out' legislation in Canada, suggesting that this system makes donation easier for families and improves the donor rate. Opinions against 'opt-out' are considered and debated. Finally, other donation systems as well as potential methods to encourage organ donation are briefly discussed.

\section{RÉ S U Ḿ}

Ce commentaire appuie la mise en place d'un système avec option de retrait ('opt-out' system en anglais) pour le don d'organes au Canada. Tout d'abord, ce commentaire se penche sur l'état actuel du don d'organes dans notre pays et présente à la fois le modèle à option d'adhésion ('opt in') et celui à option de retrait ('opt out'). Puis, il argumente en faveur de la mise en œuvre d'une législation qui permettrait un système avec option de retrait au Canada, suggérant que cela faciliterait le don d'organes pour les familles et améliorerait les taux de dons. Certains des arguments contre le système avec option de retrait sont examinés et démontés. Finalement, d'autres systèmes de dons, ainsi que des méthodes pouvant possiblement encourager le don d'organes, sont discutés brièvement.

\section{INTRODUCTION}

Today, due to the combination of advancements in medical science and our aging population, the topic of organ donation is very noteworthy. From paediatric cases to chronic disease, transplantation of organs has become the gold standard treatment for many patients. It can allow many to regain a good standard of living as well as avoid costly and time-consuming chronic treatment. In 2014, there were 4,500 Canadians waiting for transplants, with just over 2,300 transplants performed in the same year [1]. For the survivors, waiting times can take up to years [1]. Unfortunately, of the $48 \%$ who were non-recipients, about 300 patients died in the same year [1]. Despite its many advantages, organ donation continues to be quite an emotional topic for most of the population. This is understandable, as the topic involves death of a loved one, family, and our own mortality. This easily elicits questions of an ethical, religious, and scientific nature.

\section{CURRENT SITUATION IN CANADA}

In Canada, each province and territory is responsible for its own donor registry. Most provinces operate with a registration form that is filled out in person, on paper, or online. Some provinces, such as New Brunswick, have an option available to confirm donation when renewing a health card. Others have a combination of both systems $[1,2]$. With many varied systems available to Canadians, the process of registering to become an organ donor is not as easy as it seems. In efforts to manage the function of organ donation and transplantation, the provinces requested a federal agency to oversee the many different processes that ex- ist. Today, the Safety of Human Cells and Tissues and Organs for Transplantation Regulations assist Health Canada and Canadian Blood Services in managing organ donation [1]. With Canadian donation rates just under 20 donors-per-million-population, the steps that provincial and federal governments have taken seem to be lacking $[3,4]$. It would be preferable to have a streamlined system in place in Canada, uniform in all provinces. Having an efficient system would potentially encourage donation and boost donor rates.

There are two popular organ donation systems currently in place around the world. To begin, there is an 'opt-in' system. For this method to work, a person who wishes to become an organ donor must register in some fashion to be put on the available donor list. Conversely, the second system is called 'opt-out'. This system operates under the assumption that the majority of the population wishes to donate and therefore a person must express a refusal or remove their name from a list if they choose not to become a donor [5]. Currently, Canada is operating under an 'opt-in'-like system $[1,6]$. Here, we will consider the benefits of an 'opt-out' system.

\section{ARGUMENTS FOR AN ‘OPT-OUT’ SYSTEM}

The main argument for an 'opt-out' system stems from the logic that since the entire population is automatically on the list, the donor rate must naturally improve and subsequently, the number of transplants. In general, this idea is thought to promote organ donation. Many studies have been dedicated to confirming this hypothesis $[5,6]$. However, one must be careful when com- 
paring donor and transplant rates in different countries. Information is treated differently across countries and the collection of statistics can introduce bias. For example, the cause of death and cultural differences can have an impact on donor statistics [7]. Furthermore, one must consider global trends while comparing donor rate increases. Yet, even while controlling for determining factors, studies show that 'opt-out' legislation increases donor rates $[5,6,8,9]$. For example, the donor rate in Austria quadrupled after instituting 'opt-out' legislation. Similar regulations in Belgium doubled kidney donations [9]. In 2010, European countries with 'opt-out' systems such as Croatia, Portugal, and France had higher donation rates than 'opt-in' countries [9]. These trends continue today [3]. Along with new legislation, better transplantation infrastructure, public opinion, and family education also help increase the donor rate [5].

An 'opt-out' system also has the potential to assist families in the decision to donate. The death of a loved one is unfortunate, but the decision to donate organs is a topic that must rapidly be discussed. This choice often falls to the families. Many relatives are unaware of their deceased's wishes, having never discussed the issue. In addition, this is understandably a painful and confusing time for families and the decision is not easy. This could potentially result in a higher rate of refusal. Kennedy et al. suggest that during the discussion of organ donations, the 'opt-out' system allows families to be partially relieved of the burden of deciding [7]. The families have transitioned into a position of corroborating facts instead of pushed into making a timely decision [7]. It is easy to see how this would relieve stress and conflict during the moments following the death of the patient.

\section{DRAWBACKS OF THE 'OPT-OUT’ SYSTEM}

There are many who have strong opinions against the presumed consent system. For example Fabre, professor of clinical sciences at King's College London, has been very vocal in his opinions, calling the 'opt-out' scheme "unnecessary and corrupting" [10]. This is an understandable position. As we have stated at the beginning of the article, the topic of organ donation forces us to pose many ethical questions. A common argument against 'opt-out' is the aspect of informed consent. Fabre is right in calling informed consent a corner stone of medical ethics [10]. However, informing the public can be achieved by having health care professionals explain the program during regularly scheduled appointments. Public service campaigns could also have an impact on informing the community. Saunders, lecturer in philosophy at the University of Stirling, has an interesting definition of the 'opt-out' system. He suggests that 'opt-out' and presumed consent systems are different [11]. For example, Saunders states that a presumed consent system would not be preferable because "consent is not something that can be presumed". On the other hand, by using the 'opt-out' system, those who have not withdrawn their con- sent have implicitly consented, and this is therefore considered to be the act of consenting and does not presume consent [11]. Furthermore, considering the 'opt-in' system currently in place, we can ask ourselves if it is right to reject the organs of someone who has failed to register. The wishes of the person who failed to register should still be taken into account. A 2015 study showed that the 'opt-out' model was preferred to the 'opt-in' model when trying to maximise the proportion of people who had their end-of-life wishes respected [9]. 73\% of Canadians would donate their organs; however today, less than $20 \%$ have registered as a donor or have made other plans to donate $[2,12]$. In an 'opt-in' system, many Canadians will not have their wishes fulfilled because they have not registered. Similarly, these people have not consented to the discard of their organs, as it was their wish to be donors.

Moreover, there are some who speculate that an 'opt-out' system will incite a social pressure to donate and in turn diminish the attractiveness of organ donation [7]. For example, Chile enacted an 'opt-out' law in 2010 after seeing donor rates drop by $40 \%$. The sudden pressure of this change spurred public unease and millions of opt-outs. However, surveys showed that $70 \%$ of people did not fully understand the new law [5]. We can be reasonably sure that this will not be the case in Canada. There are encouraging statistics that show the majority of the population is in favour of organ donation [2,4,12]. As mentioned above, we can see that similar legislation has been accepted in other countries $[5,7,9]$.

To make an 'opt-out' system work, it is evident that a strong public education campaign will be necessary. This campaign would have many functions. For example, informing the public of their rights, of how to 'opt-out', and informing them of the implications of becoming a donor. Thankfully, as discussed earlier, Canada already has federal systems in place to promote this type of campaign [1].

\section{OTHER SYSTEMS}

There are other potential donor systems that are not discussed in detail in this commentary. For example, mandated consent is a system where persons of age would be required to decide if they wish to become donors [13]. There could also be other options, besides legislation that would have the potential to improve donor rates. Financial incentives for donations could be used. Xenotransplantation is an interesting alternative involving the transplant of other species organs into humans [6]. A reciprocal system, where to receive an organ you must be registered as a donor and be willing to donate, has also been discussed by authors [5]. However, these systems are not widely implemented and the literature exploring these systems is not well established. Increasing awareness and improving consent rates from families 
is the best option [6]. For this reason, an 'opt-out' system would still be preferable to other systems.

\section{CONCLUSION}

In conclusion, an 'opt-out' system could be suitable for Canada. It could streamline the registration process and boost donation numbers, as shown in many other countries. Even though there are perceived shortcomings with this system, it could still lead to increased donor rates in Canada. Because the majority of Canadians wish to donate, we can be reasonably sure that this new legislation, if introduced, would be widely accepted.

\section{REFERENCES}

1. Government of Canada. Blood, Organ and Tissue Donation [Internet]. Ottawa (ON): The Government of Canada, Department of Health; 2017 [updated 2017 Jan 26; cited 2017 Feb 28]. Available from: http://healthycanadians. gc.ca/diseases-conditions-maladies-affections/donation-contribution-eng. php.

2. Canadian Transplant Society. Register Your Consent [Internet]. Toronto (ON): The Canadian Transplant Society; 2014 [cited 2017 Feb 28]. Available from: http://www.cantransplant.ca/home/organ-and-tissue-donation-consent/.

3. European Directorate for the Quality of Medicines and HealthCare. Newsletter Transplant; International figures on donation and transplantation. 2016. Volume 21.

4. Canadian Blood Services. Organ Donation and Transplantation in Canada; System Progress Report 2006-2015. Ottawa. 2016.

5. Zúñiga-Fajuri A. Increasing organ donation by presumed consent and allocation priority: Chile. Bull World Health Organ. 2015;93:199-202.

6. Abadie A, Gay S. The impact of presumed consent legislation on cadaveric organ donation: A cross-country study. J Health Econ. 2006;25:599-620.

7. Kennedy I, Sells RA, Daar AS. et al. The case for "presumed consent" in organ donation. Lancet. 1998;341:1650-52.

8. Van Dalen HP, Henkens K. Comparing the effects of defaults in organ donation systems. Soc Sci Med. 2014;106:137-42.

9. Ugur ZB. Does Presumed Consent Save Lives? Evidence From Europe. Health Econ. 2015;24:1560-72.

10. Fabre J. Presumed consent for organ donation: a clinically unnecessary and corrupting influence in medicine and politics. Clin Med (Lond). 2014;14(6): $567-71$.

11. Saunders B. Opt-out donation without presumptions. J Med Ethics. 2012;38:69-72

12. Léger Marketing. Les dons d'organes; Rapport. Montréal, Québec. March 2004.

13. Spital A. Mandated Choice : The Preferred Solution to the Organ Shortage?. Arch Intern Med. 1992;152(12):2421-4. 